dents for a Democratic Society. Psychological and sociological studies dominate the second chapter, which investigates the causes of student activism. The literature selected suggests the various roles played by institutional structures and social factors. An excellent section of the chapter examines the role played by the mass media in projecting a public image of contemporary campus life. The final chapter covers publications which present philosophical and administrative approaches to problems of student activism.

The authors have selected a broad range of literature for their work. They include journalistic, on the spot accounts of specific episodes of activism. A little less along the journalistic line are published interviews with and statements by administrative, faculty, and student leaders. Also included are research studies by highly respected scholars in various disciplines.

When reading reviews of the literature, this reviewer often questions whether the author really has a creative scholar's feel and understanding of the topic. Ellsworth and Burns do seem to be on familiar ground and they comfortably handle the material in a readable fashion. Their work is comprehensive, seemingly objective, and reasonably selective. Perhaps their efforts would have more utility if the authors had ventured to construct in graphic, or other form, proposed models based upon the studies reviewed which might channel student activism along manageable and constructive lines.

The monograph concludes with a lengthy and excellent selected bibliography of books, scholarly and journalistic articles, government documents, U.S. Supreme Court decisions, and commission reports. Appended to the bibliography is a useful listing of "Related Psychological Studies."

Unfortunately, some of the best sources appear only in the bibliography and are not discussed in the text, whereas the text relies rather heavily upon sources which are perhaps more current, but which are not as reliable and which are of less enduring value. Thus, many of the sources which appear to offer the most promising suggestions to the campus community are relegated to a mere listing in a lengthy bibliography, whereas portions of many journalistic and other descriptive reports are presented at some length in the text. The authors are careful to avoid an overdependence upon quoting directly from their sources. However, they frequently fail to cite the page number from which a quotation was taken.

This monograph successfully gives the reader an overview of student activism and then proceeds to direct him in an informed manner to the major sources in the field. It is recommended for institutions of higher education, behavioral science research centers, and larger public libraries.-Willis $\boldsymbol{M}$. Hubbard, Eureka College, Eureka, Illinois.

\section{The Librarian Speaking: Interviews with}

University Librarians. Guy R. Lyle.

Athens: The University of Georgia Press, 1970. 206p.

Guy Lyle, librarian at Emory University, presents to the profession the informed opinions of a number of generally respected librarians on the "persistent and critical problems of university librarianship in the United States in the 1960's"-no small chore. $\mathrm{He}$ recognizes that interviews have their limitations, as indeed they do, but if that device does not put the reader off, he will find this book of considerable interest. It should be recommended to young librarians, who, alas, like the young everywhere, have little knowledge, less experience, and no concept of history. The librarians interviewed were selected on a "purely arbitrary" basis.

The age range of the librarians ranges from forty to sixty-eight with the average age fifty-seven, and the median age sixty. Only four of the sixteen are under fifty. The Messrs. Downs, Logsdon, Rogers, and Vosper are here, as are Kaser, Eldred Smith (the youngest man interviewed), Dix, Tauber, and others. To disprove that he's a male chauvinist pig, Lyle has included Ruth Walling, his own respected colleague. (Women may, and probably will, be able to make something of the inclusion of only one female.) It is always tempting to criticize the author for not writing a book other than the one he has, and this age issue may not be very important, so rather than do the former and stress the latter, this reviewer will but lament the fact that only one librarian educated after the second German 
war has been included. A companion volume may be in order.

The range of problems Lyle discussed with his colleagues is broad. Familiar questions about compact shelving, library hours, collection development, and cooperation are discussed, as are automation, the role of the emergent Young Turks in the professions, blanket orders, library unions, library governance, and relationships of librarians to faculty. Throughout the book, often only implicitly, concern for the future of libraries as we now know them is apparent. The professional literature is, of course, rich in material on this subject and we are all not only curious about what's to become of $u s$, as it were, but what role the rich collections we have developed down through the decades will play in tomorrow's higher education. Most of us think, and most of Guy Lyle's sixteen librarians would agree, that the book is here to stay. Whether it will be acquired, processed, housed, and used as it has been in the past is another matter.

From among Lyle's librarians, readers may identify and select their own charlatans, incompetents, or muddled sentimentalists as this reviewer has done. Those few excepted, this is a group of strong librarians deeply concerned about their profession. They are not, happily, intoning palinodes to a golden past, but, in spite of their decrepitude in the eyes of my students (whom I had read the book for a course I teach), they have realistically evaluated the profession's successes and accepted the fact that not only is change inevitable, but that it is desirable. They are equally realistic in recognizing the economic problems of higher education, the development of changing educational concepts, the necessity of finding more sophisticated technological solutions to library problems, and the need for a new kind of librarian, better trained, better educated, and more intimately involved in the whole educational process than we have had heretofore.

On the whole, a useful and interesting book. It is good to have the profession's leaders firmly on record and all of us can look forward to throwing their words in their teeth on occasion, but (and probably more frequently) also rereading them with profit.-Stuart Forth, University of Kentucky.

\section{BOOKS RECEIVED}

Note: The titles listed represent books received at the editorial office that may be of interest to academic librarians.

American Library Association, Alternatives in Print: An Index and Listing of Some Movement Publications Reflecting Today's Social Change Activities. Columbus, Ohio: The Ohio State University Libraries, 1971. 168p. \$3.50. (74-634067).

Audio Visual Market Place: A Multimedia Guide. 1971 ed. New York and London: R. R. Bowker Company, 1971. 234p. (69-18201). (ISBN 0-8352-0418-9).

Axford, Lavonne B. Educational Programs for the Gifted. Metuchen, N.J.: The Scarecrow Press, Inc., 1971. 282p. \$7.50. (70142230). (ISBN 0-8108-0366-6).

Baer, Eleanora A. Titles in Series: A Handbook for Librarians and Students. Second Supplement to the Second Edition. Metuchen, N.J.: Scarecrow Press, Inc., 1971. 509p. (64-11789) (ISBN 0-81080356-9).

Banks, Arthur S., assembler. Cross-Polity Time-Series Data. Cambridge, Mass. and London: The M.I.T. Press, 1971. 300p. $\$ 30.00$. (78-133838). (ISBN 0-26202071-8).

Bartran, Margaret. A Guide to Color Reproductions, $2 \mathrm{~d}$ ed. Metuchen, N.J.: The Scarecrow Press, Inc., 1971. 625p. (74142231). (ISBN 0-8108-0343-7).

Bell, James Edward. A Guide to Library Research in Psychology. Dubuque, Iowa: Wm. C. Brown Company Publishers, 1971. 211p. \$2.95. (ISBN 0-69706609-6).

Bernal, J. D. Science in History. (4v.) Cambridge, Mass: The M.I.T. Press, 1971. 1328p. + indices. \$15.00. (78136489). (ISBN 0-262-52020-6).

Better Teachers. Paris: UNESCO, 1970. 212p. \$3.50.

Bode, Carl, ed. The Best of Thoreau's Journals. Carbondale: Southern Illinois University Press, 1971. 329p. + index and bibliography. $\$ 8.95$. (67-15321). (ISBN 0-8093-0475-9).

Borrello, Alfred. An E. M. Forster Dictionary. Metuchen, N.J.: The Scarecrow 